\title{
POROUS CONCRETE
}

\author{
Milica Pavić ${ }^{1}$ \\ Ljiljana Kozarić ${ }^{2}$
}

UDK: 666.973 .3

DOI: $10.14415 /$ konferencijaGFS2021.21

Summary: Porous concrete belongs to the group of lightweight concrete with a bulk density of 1600 to $2000 \mathrm{~kg} / \mathrm{m}^{3}$. It is a mixture of cement, aggregate, water, and if necessary additives. The single-fraction coarse aggregate allows high porosity, resulting in high permeability. The permeability property increases the use of porous concrete, especially for the construction of driveways, sidewalks and parking lots.

Keywords: porous concrete, application, properties

\section{INTRODUCTION}

After the Second World War in Europe, after great destruction, the increasing use of porous concrete began due to the lack of construction materials. With that, serious tests of the properties of porous concrete began, and it belonged to the group of cheaper construction methods. In the United States, it is less applied, because they did not have problems with the lack of construction materials.

Porous concrete is a special type of concrete that differs from ordinary concrete by its pronounced porosity. It is an environmentally friendly material which, in addition to high porosity is also characterized by high strength. Which is why it is increasingly used in construction, and especially in the construction of roads and environmentally friendly buildings.

This paper describes porous concrete with its characteristics, components and application in construction.

\section{POROUS CONCRETE}

Porous concrete is also called seepage or permeable concrete, according to the name it can be concluded that its main role is to let water from the concrete surface into the lower layers. Due to its structure, as well as possibility of combining different types of aggregates and colors in concrete, porous concrete is a good solution for architectural challenges.

\footnotetext{
${ }^{1}$ University of Novi Sad, Faculty of Civil Engineering, 2a Kozaračka Str., Subotica, Republic of Serbia, e-mail: pavic953@gmail.com

${ }^{2}$ University of Novi Sad, Faculty of Civil Engineering, 2a Kozaračka Str., Subotica, Republic of Serbia, e-mail: kozaric@gf.uns.ac.rs
} 
Савремена достигнућа у грађевинарству 22-23. април 2021. Суботица, СРБИЈА

The application of porous concrete is wide, and it is most often used for the production of sidewalks and pavements, driveways, parking lots, parks, paths and roads in the natural environment, areas near swimming pools and beaches, as decorative concrete, etc, Figure 1 [4]. In cold climates, the use of porous concrete is limited, due to low compressive strength, the possibility of clogging, more pronounced shrinkage, and poor resistance to freezing and thawing.

Porous concrete is not difficult to install, but it differs from standard concrete and appropriate installation techniques are required in order to achieve its effectiveness. It has a relatively rigid consistency that requires special placement and installation conditions. It is important to use a vibrating plate to achieve optimal density and strength. After that, the material is compacted with rollers and it is not necessary to use tools for leveling the surface. Expansion joints can be formed shortly after consolidation or notched using conventional cutting equipment. However, cutting can cause the concrete to crack at the joint. Porous concrete pavements can be without expansion joints [4].

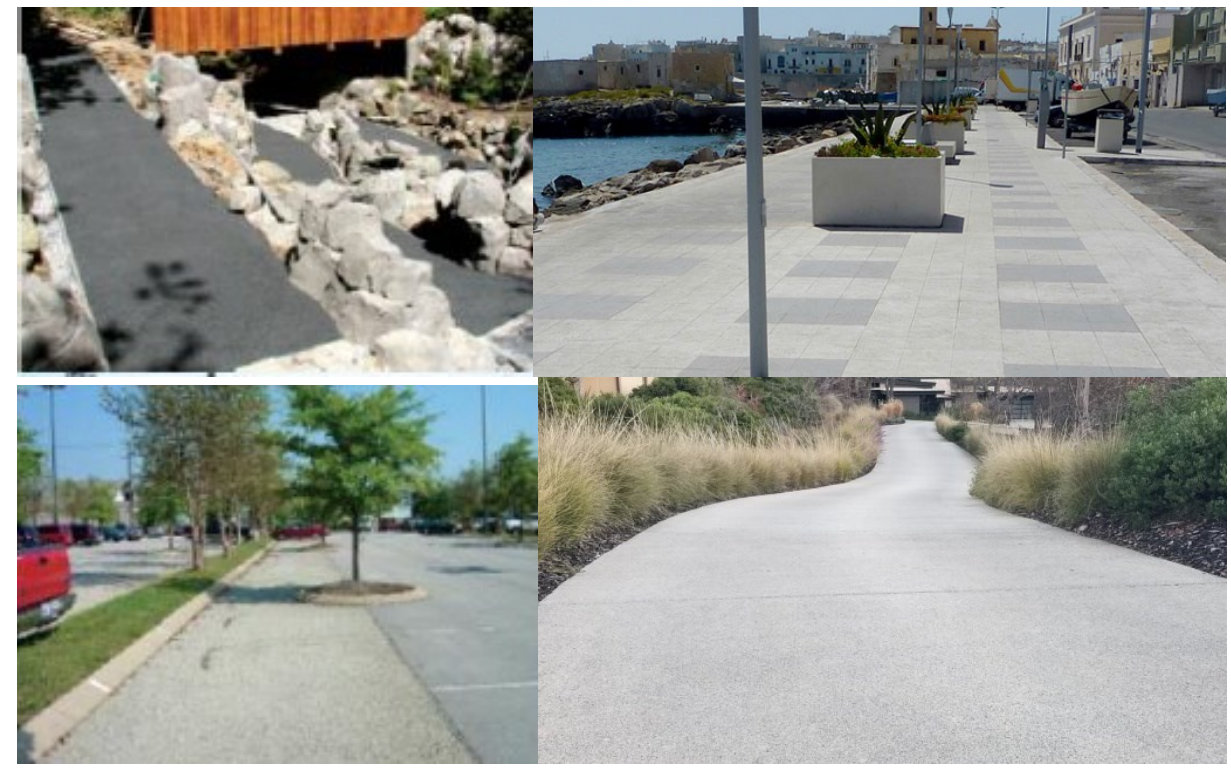

Figure 1. Examples of porous concrete application [4]

\section{MATERIALS}

To obtain concrete of adequate strength, porosity, and permeability, it is important to select the appropriate concrete ingredients and their interrelationship. Porous concrete is a mixture of cement, aggregate, water and, if necessary additives.

\subsection{Aggregate}

The aggregate is generally single fractional, with a granulation of 4 to $8 \mathrm{~mm}$, in exceptional cases $12,5 \mathrm{~mm}$, with or without the addition of fine particles. Mostly crushed stone or river grave is used because larger aggregates create higher porosity by increasing permeability, 


\section{$8^{\text {th }}$ inteRnAtional CONFERENCE}

Contemporary achievements in civil engineering 22-23. April 2021. Subotica, SERBIA

and aggregates of smaller dimensions enable greater workability of the mixture. If fine particles are added, they are added in the amount of $7 \%$ concerning the total mass of the aggregate [9]. Because it contains a small amount of sand, a large amount of pores is created. Sand increases mechanical strength but reduces porosity and permeability [8]. The bulk density of porous concrete ranges from 1600 to $2000 \mathrm{~kg} / \mathrm{m}^{3}$.

\subsection{Cement}

Cement and Portland cement are used as bonding materials, as well as for ordinary concrete. Additional cement materials, such as fly ash, pozzuolana and slag may be used. It is recommended to test the material before installation in order to determine the properties important for the installation of concrete, such as installation time, rate of strength development, porosity and development [1].

It is common to use mineral additives to replace parts of the cement, such as fly ash or slag. One example of the recommended granulometric curves of aggregates in the design of porous concrete mixtures is shown in Figure 2 [10].

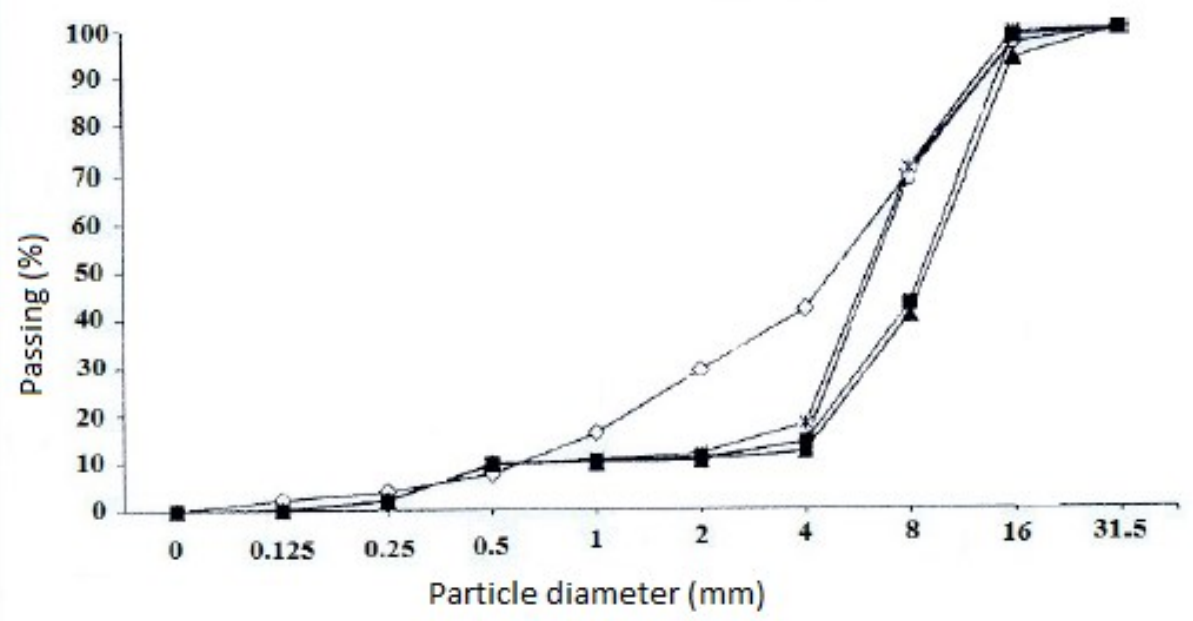

Figure 2. Recommended granulometric curves of aggregates [10]

\subsection{Water}

Water control is important in the development of permeable concrete mixtures, and the selection of the appropriate $\mathrm{V} / \mathrm{C}$ value is essential for obtaining the desired strength and porosity in concrete. Large $\mathrm{V} / \mathrm{C}$ can cause cement paste to leak out of the aggregate and fill the void structure, while small V/C can lead to mixing, setting, and reduced durability. $\mathrm{V} / \mathrm{C}$ values between 0.27 and 0.34 are usually used [6]. Figure 3 shows an example of porous concrete in fresh condition depending on the amount of water. 


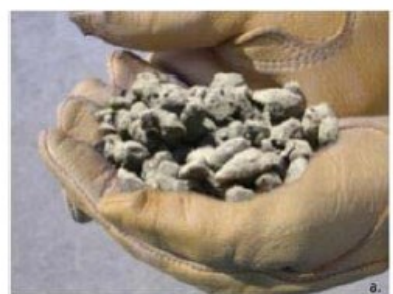

a) too little water

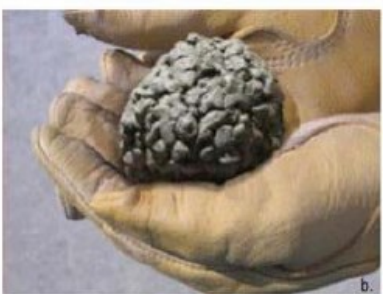

b) proper amount of water

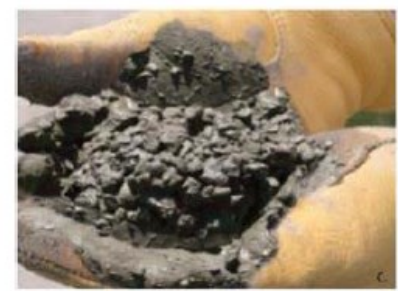

c) too much water

Figure 3. Workability assessments for porous concrete [5]

\subsection{Admixtures}

The following following admixtures can be used for porous concrete :

- for water reduction

- for stabilization and hydration control

- $\quad$ for installation of porous concrete at low temperatures

- $\quad$ in areas sensitive to freezing and thawing cycles, aerants are used

- doping evaporation

- $\quad$ fibers used to improve durability in cold areas [3].

To prepare a mixture of porous concrete, a certain amount of water and cement materials are used to make paste/stuff, so that the aggregate grains are evenly covered with paste, but so that the excess paste/stuff does not fill the cavities in the coarse aggregate. Using a sufficient amount of concrete for coating and bonding the aggregate grains creates a composition of highly permeable, interconnected cavities that drain water quickly [6].

At higher pore contents, compressive strength (20-30 MPa) and flexural strength (up to 6 $\mathrm{MPa})$ decrease, while the water flow rate increases. Water permeability, with a cavity content of $15 \%$ to $25 \%$ in hardened porous concrete is about $2001 / \mathrm{m}^{2} / \mathrm{min}$ [4].

When determing the optimal mixture for making porous concrete, it is better to modify the proportions and properties of the aggregate, such as granulation, siye and quantity, than to change the level of compaction to obtain the desired proportion of cavities.

\section{PROPERTIES}

The mechanical behavior of a building material largely depends on its composite structure. The strength of porous concrete depends on the amount of cement, water cement ratio, degree of compaction and aggregate fraction. In order to achieve the workability with angular aggregate, more paste should be provided than for porous concrete which contains a round aggregate of uniform size. But porous concrete with angular aggregate has a higher compressive strength than concrete consisting of aggregate lining, which was obtained by testing samples of porous concrete, same density and porosity [1]. Adding a small amount of sand (about $5 \%$ by volume) increases the bending strength of porous concrete. Also, the bending strength is increased by using polymer additives [2].

In order to obtain the required constant gap and sufficient strength, the most important condition is to maintain the continuity of the cement paste with the built-in coarse 
Contemporary achievements in civil engineering 22-23. April 2021. Subotica, SERBIA

aggregate. This can be achieved by using a cement paste with a relatively small water cement ratio $(\mathrm{V} / \mathrm{C})$ and sufficiently mixing time [11]. Therefore, the knowledge of the rheology of cement paste is a basic requirement for the preparation of a good cement paste for the production of porous concrete.

Compressive strength is related to the strength of the paste and aggreagate and the ratio of voids. For porous concrete with a good aggregate, the strength of the paste is an important factor because the strength of the aggregate is genereally higher than the strength of the paste. After mixing, the paste covers the aggregate and acts as a whole with air-filled cavities. The presence of pores can adversely affect the mechanical properties of the material such as fracture toughness, elasticity and creep deformation.

Many researches have been conducted, in Figure 4 we see an example of one research, i.e. the relationship between $\mathrm{V} / \mathrm{C}$, cement and compressive strength.

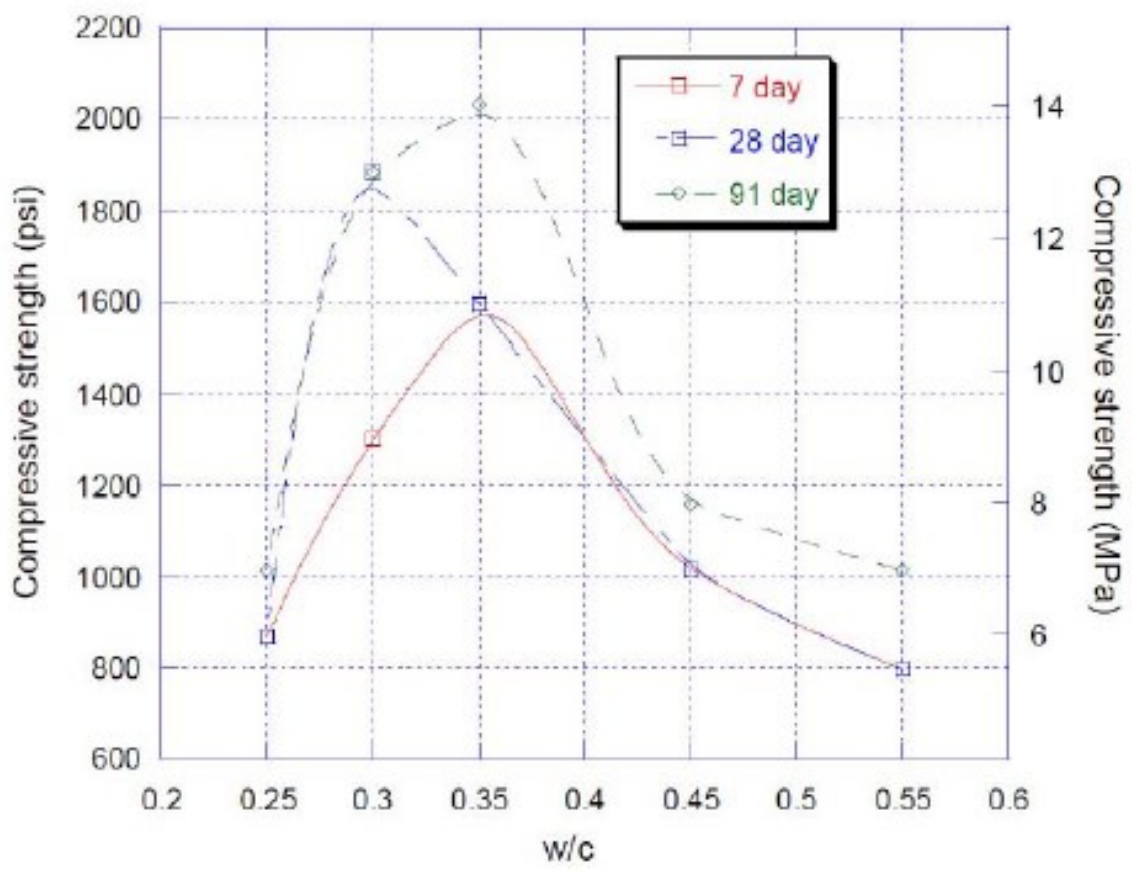

Figure 4. Relationship between Water-to-cement and Compressive Strength [12]

Under load, the presence of cavities is a weakness, because cracks are created due to stress [11]. The percentage of voids in concrete is initially about $50 \%$ for all mixtures. With vibrations, the ratio of cavities decreases, and the decrease is greater with increasing vibration energy.

Drying shrinkage in porous concrete develops earlier, but is less than in standard concrete. Specific values depend on the materials used and their participation. Values are around $2 \times 10^{-4}$ almost twice less than with conventional concrete. About $50-80 \%$ of shrinkage occurs in the first 10 days, and in use $20-30 \%$. Due to the lower shrinkage and surface texture, many porous concretes are made without expansion joints and are left to crack at random. [4] 


\section{CONCLUSION}

The use of porous concrete has increased significantly in recent years, mainly because it is considered an environmentally friendly material. Its application reduces the noise that occurs during the contact between the tires and the road, helps to reduce the temperature in cities, as well as to improve air quality. It is applied mostly due to its high permeability, which controls the outflow of atmospheric water.

As the final product is more expensive than conventional concrete, the costs are higher by $10-40 \%$. However, this is irrelevant when considering that porous concrete eliminates the need for drainage elements. It also allows better use of space.

\section{REFERENCES}

[1] Mahallingam, R., Mahallingam V., S.: Analysis od pervious concrete properties, Građevinar, 68, 2016 , pp. 493-501, (DOI: 10.14256/JCE.1434.2015)

[2] Blažok, D.: Pervious concrete for the road, Tehnički glasnik, 4, 2010, pp. 15-18

[3] www.perviouspavement.org

[4] Brnas, I.: The impact of composition and method of installation on the properties of porous concrete, University of Split, Faculty of Civil Engineering, Architecture and Geodesy, 2016

[5] Aoki, Y.: Development of pervious concrete, University of Technology, SydneyFaculty od Engineering and Information Technology, 2009

[6] Tech Brief: Perviouse Concrete, 2012, (FHWA-HIP-13-006 )

[7] Yao, A., Ding, H., Zhang X., Hu, Z., Hao, R., Yang, T.: Optimum Design and Performance od Porous Concrete for Heavy-Load Traffic Pavement in Cold and Heavy Rainfall Region of NE China, Advances in Materials Science and Engineering, 2018, (DOI: 10.1155/2018/7082897)

[8] Najm, H.: Evaluation of mechanical and hydrogogical properties of pervious concrete for use in sidewalks in New Jersey, 2017

[9] Šešlija ., Rradović, N., Trivunović, M., Bibić, D., Peško, I.: Analysis od pervious concrete pavement, International conference, Faculty of Civil Enfinnering Subotica, 2015, pp. 429-434 (DOI: 10.14415/konferencijaGFS 2015.054)

[10] Topličić-Ćurčić, G., Grdić, D., Ristić, N., Grdić, Z.: Environmental importance, comprosition and properties of pervious concrete, Original scientific paper, (DOI: 10.5937/grnk1602015T), 2016, pp. 15-27

[11] Chindaprasit, P., Hatanaka, S., Chareerat, T., Mishima, N., Yuasa, Y.: Cement paste characteristics and porous concrete properties

[12] Amde, A., M., Rogge, S.: Development of high quality pervious concrete specifications for Maryland conditions, Department of Civil and Environmental Engineering, University of Maryland, 2013 
$8^{\text {th }}$

INTERNATIONAL CONFERENCE

Contemporary achievements in civil engineering 22-23. April 2021. Subotica, SERBIA

\section{ПОРОЗНИ БЕТОН}

Резиме: Порозни бетон спада у групу лаких бетона са запреминском масом од 1600 до $2000 \mathrm{~kg} / \mathrm{m}^{3}$. Представља мешавину иемента, агрегата, воде и по потреби адитива. Једнофракиијски груби агрегат омогућава велику порозност, при чему се добија велика пропусност. Особина пропусности повећава употребу порозног бетона, нарочито за израду прилаза, тротоара и паркинга.

Кључне речи: порозни бетон, примена, својства 